Bolm Inst. oceanogr., S Paulo, 32(1):83-90, 1983

\title{
SOME OBSERVATIONS ON MARINE PHYTOPLANKTON KINETICS, 2. THE EFFECT OF NITRATE AND AMMONIUM CONCENTRATIONSON THE GROWTH AND UPTAKE RATES OF THE NATURAL POPULATION OF UBATUBA REGION, SP $\left(23^{\circ} \mathrm{S}, 045^{\circ} \mathrm{W}\right)$
}

\author{
Gilda SCHMIDT
}

Instituto Oceanogräfico da Universidade de São Paulo

\begin{abstract}
Synopsis
The phytoplankton $K s$ and Vmax as a function of ammonium and nitrate concentrations were determined. The growth rate was estimated from measurements on synthesized chlorophylz-a and the cell number in the culture media. The uptake rate was determined as to the consumption of ammonium and nitrate after the nutrients depletion from culture media.

Descriptors: Phytoplankton, Kinetics, Nitrates, Ammonium, Growth, Chlorophylls, Nutrients (minerai), Limiting factors, Cell counting, Fluorescence, Pinaeudactyium iricornutum, Ubatuba, SP.

Descritores: Fitopläncton, Cinética, Nitratos. Anônio, Crescimento, Clorofilas, Nutrientes minerais, Fatores limitantes, Contagem de célula, Fluorescência, Phacodactulum tricornutum, Ubatuba, SP.
\end{abstract}

\section{Introduction}

Marine phytoplankton, as well as all the phototrophic organisms, need light energy, carbon dioxide, water, some metallic ions, inorganic ions and organic compounds to grow. Generally, only nitrogen and phosphorus, and sometimes silicon, occur in concentrations below the optimum for phytoplankton growth. Dugdale \& Goering (1967) and Goldman et al.(1979) report that nitrogen seems to be the only element limiting the growth of phytoplankton growth in oceans. The predominant forms of available nitrogen in oceans are nitrate and ammonium. Since Dugdale 's (1967) work, the phytoplankton kinetics has been expressed in the Michaelis-Menten equation: $\mu=\frac{\text { Vmax vs S }}{\mathrm{Ks}+\mathrm{S}}$, where: $\mu$ is the specific growth rate constant; Vmax the maximum growth rate constant; S the substract (nutrient) and Ks is the Michaelis-Menten constant. The Michaelis-Menten equation, according to Droop (1974), is based on the following reactions: $\mathrm{E}+\mathrm{S} \underset{\mathrm{k}_{2}}{\stackrel{\mathrm{k}_{1}}{\rightleftarrows}} \mathrm{x} \stackrel{\mathrm{k}_{3}}{\longrightarrow} \mathrm{p}+\mathrm{E}$, where:

$\mathrm{E}$ is the microorganism; $\mathrm{S}$ is the substract (nutrient); $\mathrm{P}$ is the product and $k_{1}, k_{2}$ and $k_{3}$ are velocity constants. This work aimed to determine Ks and Vmax for ammonium and nitrate growth and uptake rates of phytoplankton natural population of Ubatuba region, and to know the influence of these two

Publ. n. 586 do Inst. oceanogr. da Usp. nutrients on the phytoplankton percentual composition.

\section{Material and methods}

The sample was collected at sea surface, with a plastic bucket. The cells contained in a $300 \mathrm{ml}$ Erlenmeyer flaskwere incubated in a BOD type incubador, at $26^{\circ} \mathrm{C}$ and 5 KLUX given by fluorescent day-1ight type lamps, continuous regime. Nitrate and ammonium were added to the flasks from 0.0 to $20.0 \mu \mathrm{g}-\mathrm{at} / 1$, a series of 8 concentrations for each nutrient. The standard solution of ammonium was prepared with ammonium chloride and the standard solution of nitrate with potassium nitrate。Chlorophy11- $a$ was determined according to Strickland \& Parsons (1968). Cell counting were made under a Zeiss inverted microscope, $600 \mathrm{x}$, with a $2.5 \mathrm{~cm}^{3}$ chamber. In vivo fluorescence was determined with a Turner fluorometer, Mode1 111, 30 X sensitivity. Nitrate was determined according to Mullin \& Riley (1955) and ammonium by the Solörzano (1969) technique. Phytoplankton carbon was determined by the wet oxidation method, described by Strickland \& Parsons (opo cito). Growth and uptake rates were calculated according to Schmidt (1982)。

\section{Results and discussion}

Figure 1 shows the sampling station. The hydrographic parameters, initial cell number, nitrate, ammonium and chlorophyl1-a concentrations are listed in Table 1. The relative composition of 


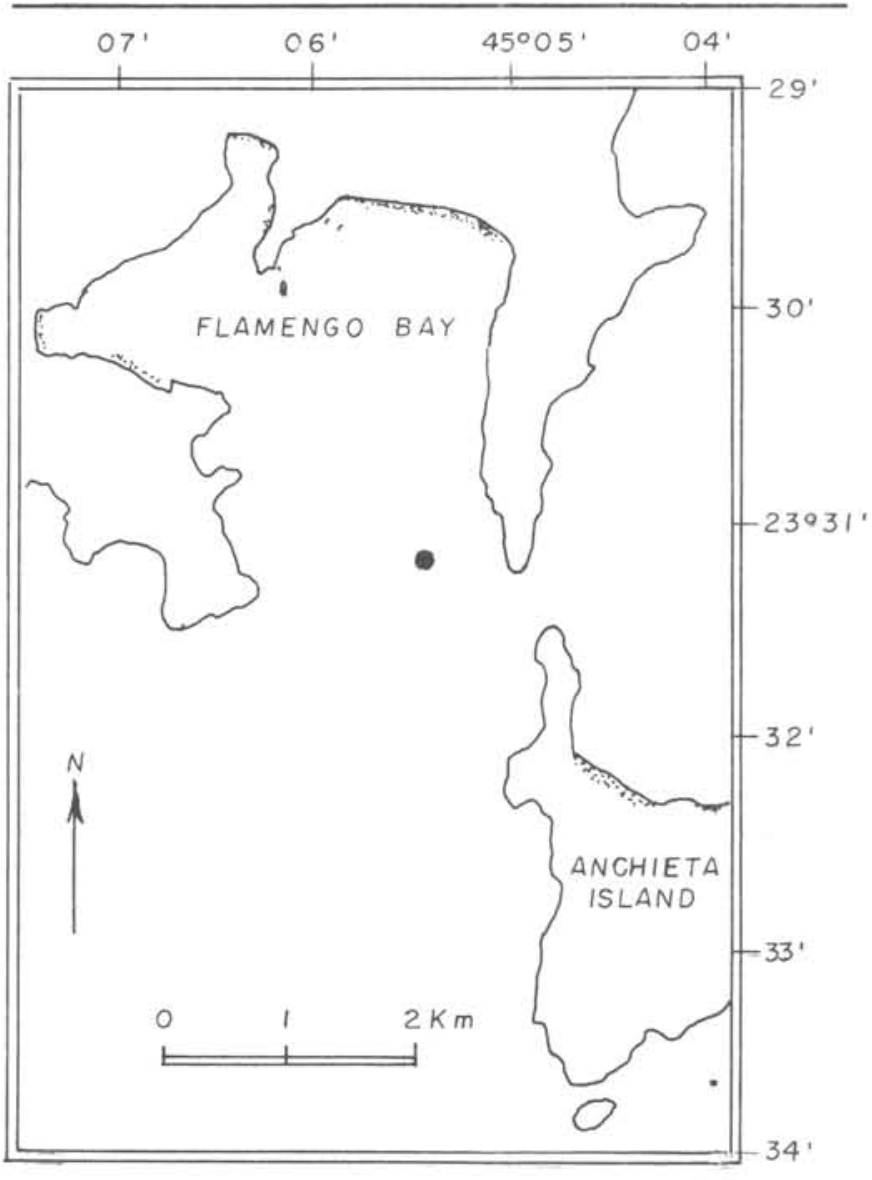

Fig. 1. Localization of the sampling station at Ubatuba region, SP $\left(23^{\circ} 31^{\prime} \mathrm{s} ; 45^{\circ} 05^{\prime} \mathrm{W}\right)$. the phytoplankton during the experiment is listed in Table 2。 The cells were grouped as phytoflagellates, diatoms, dinoflagellates, Phaeodactylum tricornutum (Boh1in) and those with non-conspicuous characteristics were listed as non-identified. A great part of the organisms listed as non-identified are likely to be phytoflagellates that lost their flagelles. In literature they are named "monad" (Hasle, 1978). The initial percentage of the flagellates agrees with Teixeira \& Kutner (1962), who observed $97 \%$ organisms smaller than $65 \mu$ in the phytoplankton from Cananéia (SP) region. Sassi (1978) recorded at Ubatuba (SP) region $86,24 \%$ of chlorophy $11-a$ produced by organisms smaller than $20 \mu$. Teixeira \& Tundisi (1967) related that in oligotrophic waters, the flagellates are relatively abundant. The sole difference recorded in Table 2 seems to be the increase, after four days of incubation, of diatom cell number in

Table 1. Hydrographic parameters, initial nitrate, ammonium, cell number and chlorophyll-a concentrations

\begin{tabular}{|c|c|c|c|c|c|c|c|}
\hline $\begin{array}{l}\text { Lecal } \\
\text { bepp: } \\
\text { int }\end{array}$ & $r^{*} t$ & $s^{*} / \ldots$ & $\begin{array}{c}0, \\
-114\end{array}$ & $\begin{array}{l}\text { noi } \\
\text { geat/1 }\end{array}$ & Nh, & $\begin{array}{c}\text { Col1 } \\
\text { numbers: }\end{array}$ & $\begin{array}{c}\text { Cnteroehyli-s } \\
\text { we/l }\end{array}$ \\
\hline 30 & 26 & 36.80 & 5.97 & 0.90 & 8.10 & $1.3 \cdot 10^{9}$ & 0.77 \\
\hline
\end{tabular}

Table 2. Percentual composition of the phytoplankton of Ubatuba (SP) region, in culture media of nitrate and ammonium

\begin{tabular}{|c|c|c|c|c|c|c|c|}
\hline $\begin{array}{l}\text { Culture } \\
\text { media }\end{array}$ & 8 & Phytoflagellates & Diatoms & Dinoflagellates & Non-identified & P. tricornutum & $\begin{array}{l}\text { Total phyto } \\
\text { ce } 11 \text { number } \\
\left(x 10^{6}\right)\end{array}$ \\
\hline & Initial & 33.57 & 9.94 & 18.57 & 37.90 & - & 0.13 \\
\hline \multicolumn{8}{|l|}{ Nitrate } \\
\hline \multicolumn{8}{|l|}{$\mu q=a t / 1$} \\
\hline 0.90 & After 4 days & 25.50 & 59.84 & 4.67 & 9.29 & 0.79 & 1.00 \\
\hline 1,60 & $\begin{array}{c}\text { of } \\
\text { incubation }\end{array}$ & 13.99 & 81.08 & 2.20 & 2.79 & 0.25 & 11.92 \\
\hline 2.00 & & 6,86 & 89.66 & 1.44 & 2.02 & 0.03 & 13.47 \\
\hline 3.00 & & 6.94 & 65.18 & 3.32 & 24.54 & 0.10 & 11.46 \\
\hline 5.00 & & 6.47 & 84.30 & 2.42 & 7.83 & 0.14 & 8.77 \\
\hline 11,00 & & 3.33 & 76.12 & 3.70 & 16.81 & 0.25 & 10.89 \\
\hline 15.00 & & 0.90 & 94.28 & 1.44 & 3.37 & 0.09 & 16.63 \\
\hline 21.00 & & 3.36 & 84.38 & 4.25 & 8.00 & 0.12 & 11.75 \\
\hline \multicolumn{8}{|l|}{ Ammonium } \\
\hline \multicolumn{8}{|l|}{$\mathrm{Hg}-\mathrm{at} / 1$} \\
\hline 0.30 & After 4 days & 5.18 & 82.65 & 2.54 & 9.42 & 0.18 & 5.35 \\
\hline 1.00 & $\begin{array}{c}\text { of } \\
\text { incubation }\end{array}$ & 5.80 & 79.60 & 2.30 & 12.23 & - & 5.36 \\
\hline 1.70 & & 2.56 & 81.34 & 1.23 & 14.76 & 0.09 & 10.53 \\
\hline 2.70 & & 3.83 & 87.09 & 0.86 & 8.16 & 0.03 & 13.83 \\
\hline 4.30 & & 4.47 & 75.25 & 3.68 & 16.48 & 0.09 & 10.10 \\
\hline 8.30 & & 4.27 & 74.41 & 2.22 & 19.08 & - & 20.22 \\
\hline 16.30 & & 7.51 & 60.91 & 4.92 & 23.70 & 2.93 & 8.52 \\
\hline 20.30 & & 2.52 & 74.98 & 2.99 & 19.28 & 0.21 & 9.51 \\
\hline
\end{tabular}


both culture media. These results are in accordance with Parsons et al. (1978) assumption that diatoms dominate over flagellates under favourable conditions. This advantage could be attributed to a higher rate of cell division or smaller loss of diatom cells。 Po tricornutum was counted because of its presence in the enriched cultures of water from the region. The chlorophy11-a/cell ratio recorded was $0.38 \mathrm{pg}$ in ammonium medium and $0.34 \mathrm{pg}$ in nitrate. The phytoplankton carbon/chlorophy11-a ratio was 48.5 . Thomas \& Dodson (1972) observed that the phytoplankton carbon/chlorophy11-a ratio decreased with the water impoverishment, being approximately 90 for eutrophic and 30 for oligotrophic waters. There was no correlation between cell number and in vivo fluorescence. The correlation value between chlorophy11- $a$ and in vivo' fluorescence in the ammonium media was 0.77 and 0.56 in the nitrate medium. Figure 2 apparently indicates a better yield of chlorophyl1- $a$ synthesis in the presence of ammonium. The consumption of ammonium was greater than that of nitrate (Fig. 3). The growth rate of phytoplankton estimated from cell number, has the same hyperbolic shape in both culture media (Figs 4-5)。Figures 6-7 show the growth rate, estimated from synthesized chlorophyl1-a, as a function of nitrate and ammonium concentrations. Figures 6-7 presents only seven points because at the lowest concentration of both nutrients, chlorophyl1- $a$ yield was $<1.00$ $\mu \mathrm{g} / 1$ and resulted in a negative rate value. The consumption of nitrate and ammonium was calculated as the difference between their initial and final values in the culture media. The uptake rate, estimated from ammonium and nitrate consumption in culture media, as a function of nitrate and ammonium, is shown in Figures 8-9. Thomas (1970) found a Ks of $1.47 \mu \mathrm{g}-\mathrm{at} / 1$ for ammonium and $0.59 \mu \mathrm{g}-\mathrm{at} / 1$ for nitrate, estimated from measurements of in vivo fluorescence for the natural phytoplankton from the Tropical Pacific Ocean, showing a better affinity of the phytoplankton for nitrate as nitrogenous nutrient. It seems that the natural phytoplankton of Ubatuba region prefers ammonium as the nitrogenous nutrient (Table 3)。McCarthy et al. (1977) observed a preference for ammonium in the Chesapeake Bay phytoplankton. They related that water presenting $63 \%$ nitrate as nitrogenous nutrient showed $22.1 \%$ utilization and that $14.5 \%$ ammonium presented $50.9 \%$

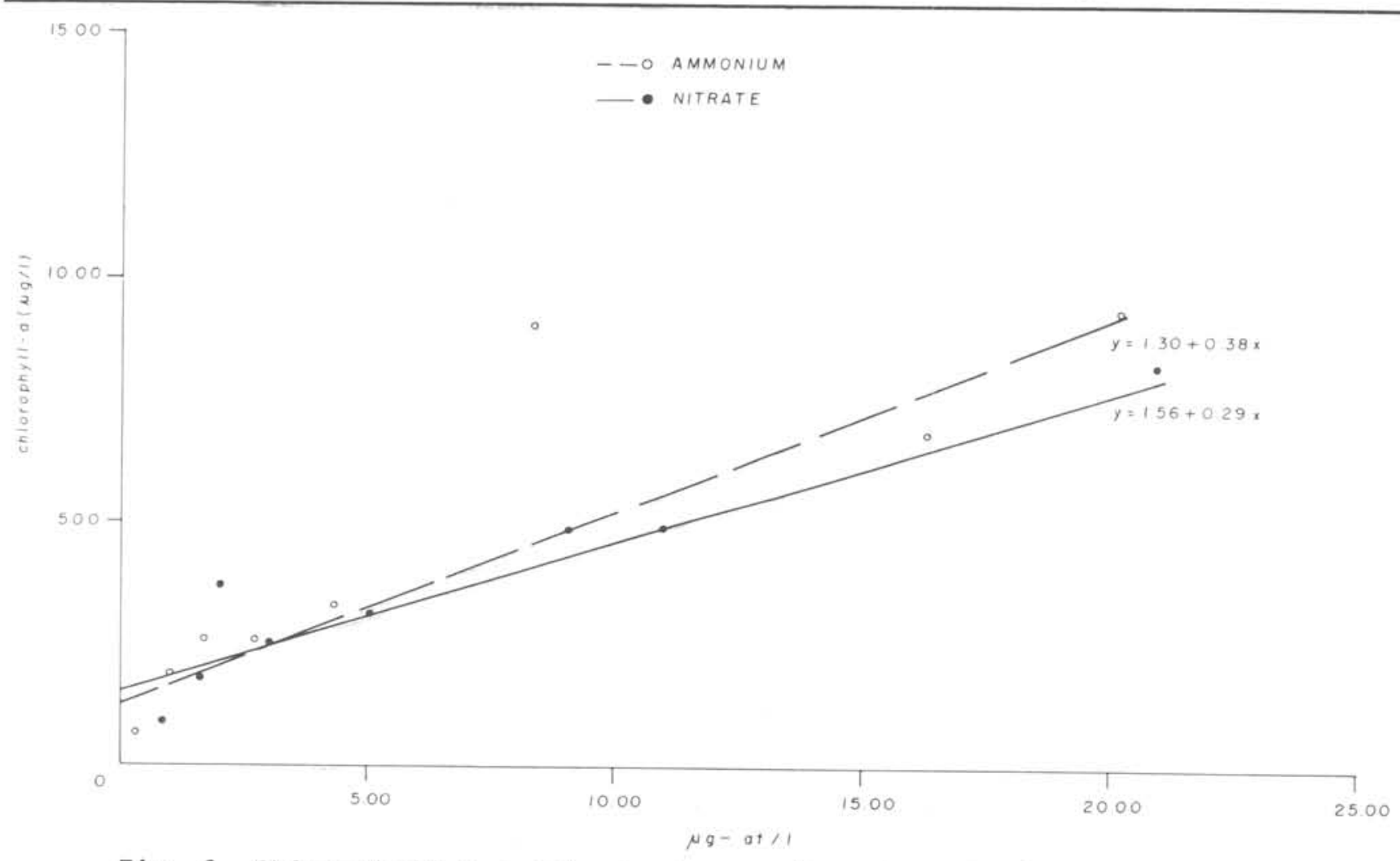

Fig. 2. Chlorophyll-a synthesized as a function of nitrate and ammonium concentrations. 


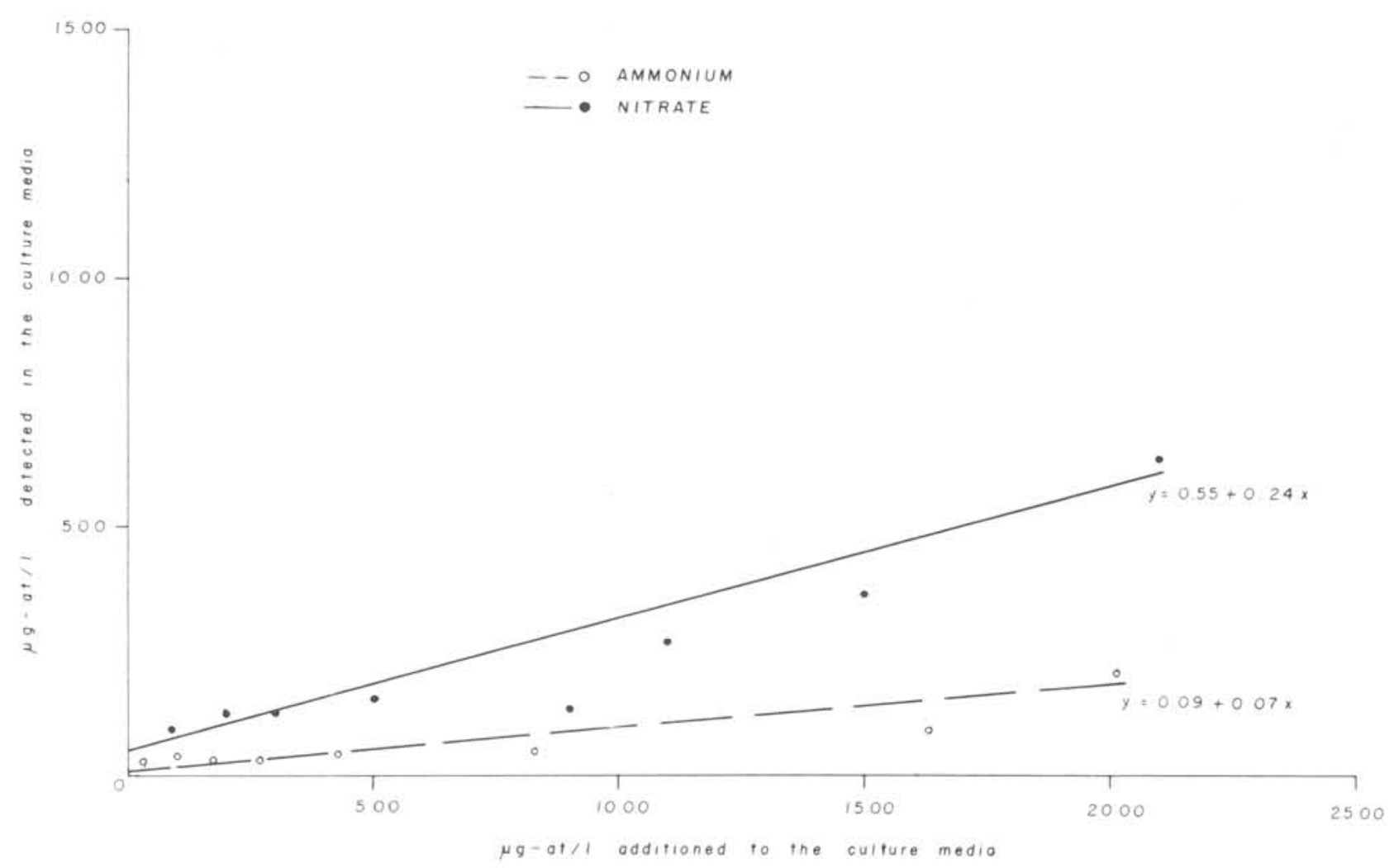

Fig. 3. Nitrate and ammonium consumed as a function of nitrate and ammonium concentrations, measured as its disappearance from culture medium.
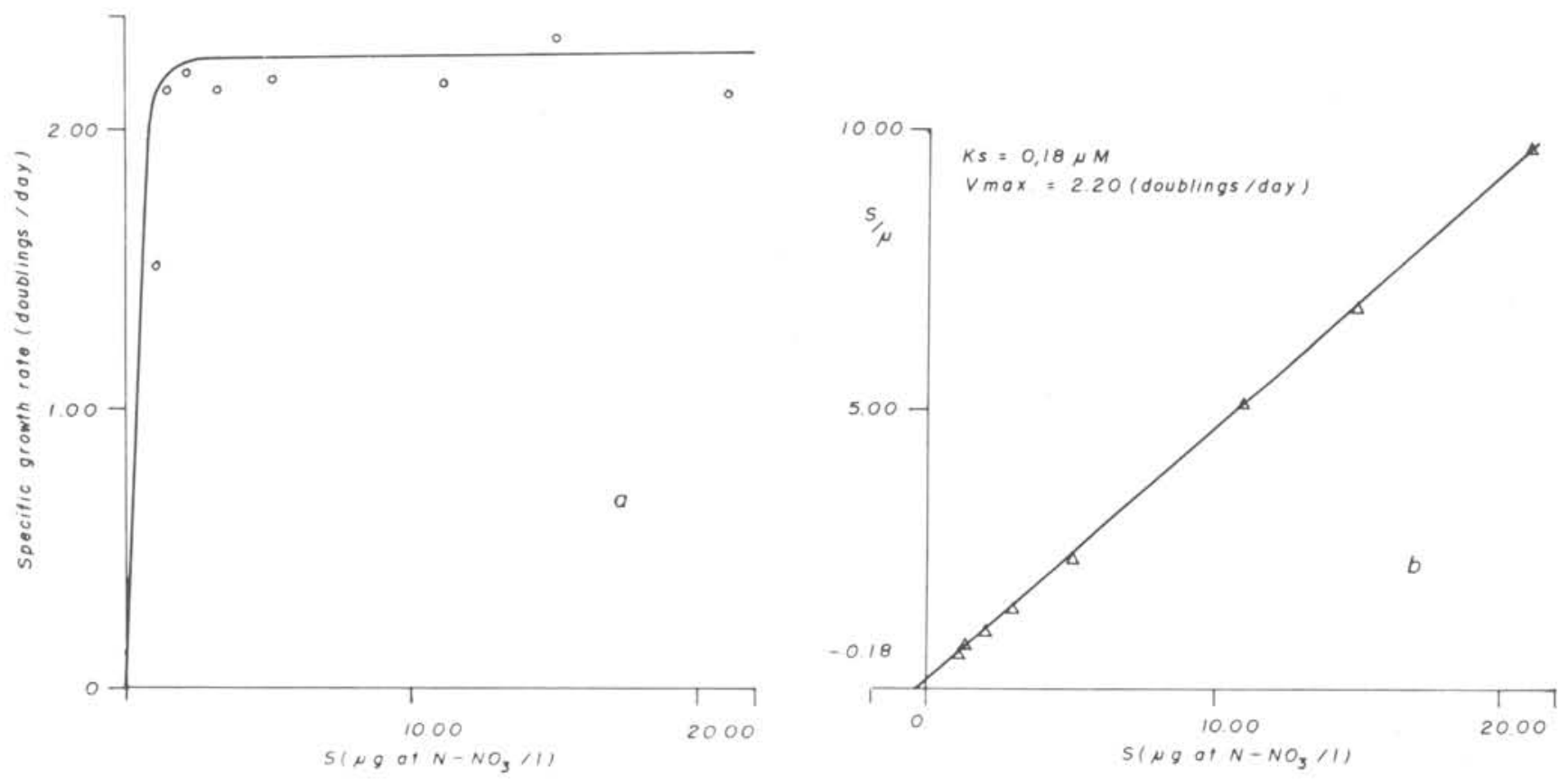

Fig. 4. a) Growth rate (doublings/day) of natural phytoplankton, estimated from cell number, as a function of nitrate concentration; b) Linearization by plotting $S$ vs $S / \mu$, to give directly $K s$ and Vmax values. 

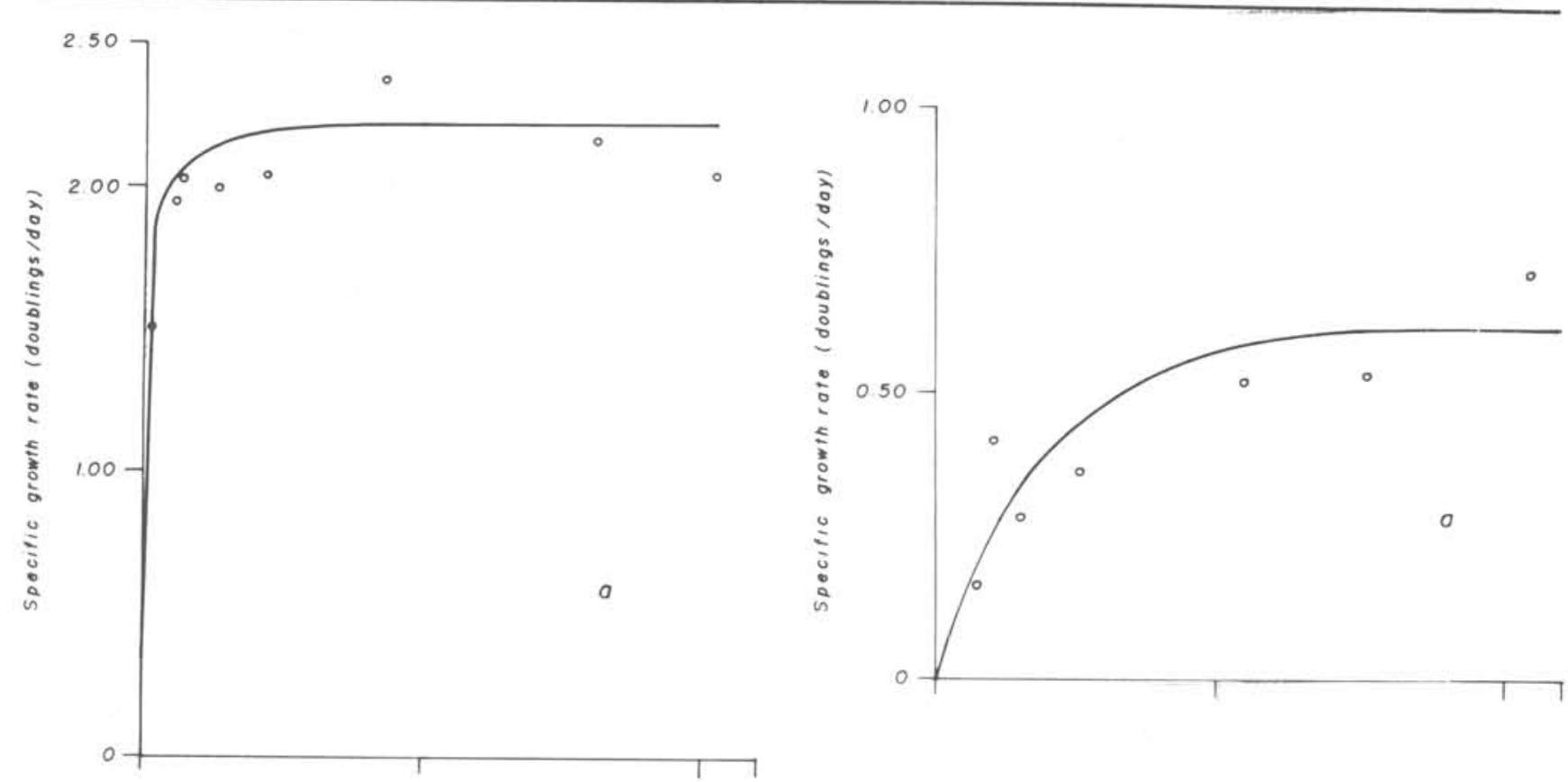

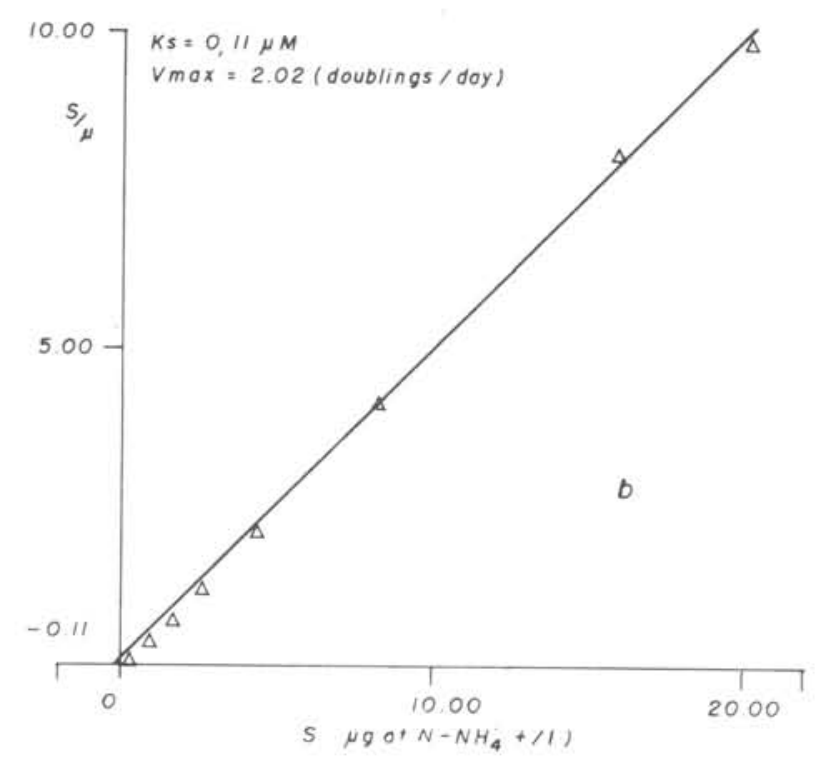

Fig. 5. a) Growth rate (doublings/day) of natural phytoplankton, estimated from cell number, as a function of ammonium concentration; b) Linearization by plotting $S$ vs $S / \mu$, showing directly $\mathrm{Ks}$ and Vmax.

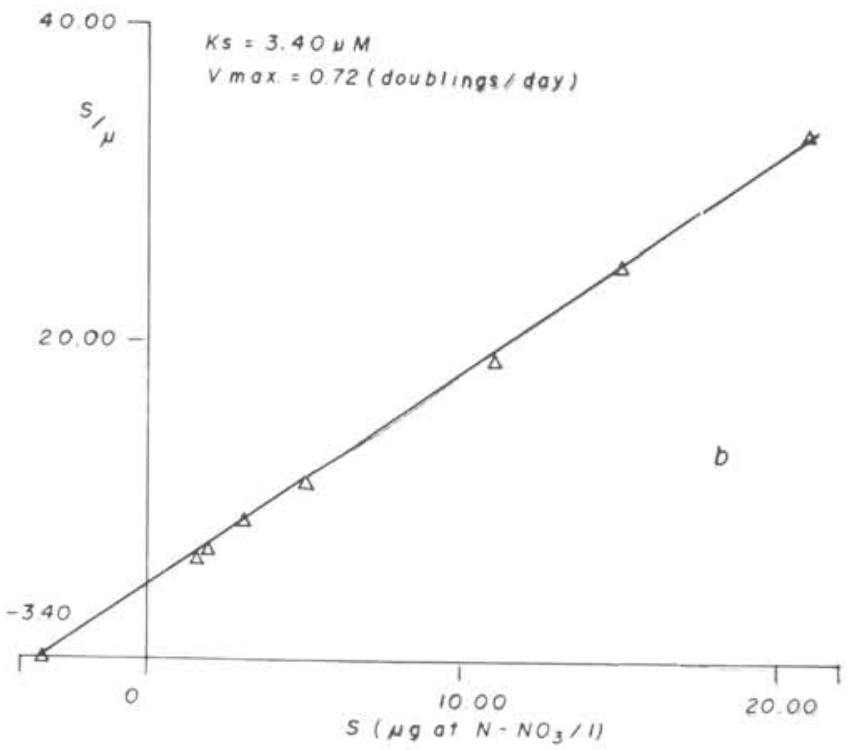

Fig. 6. a) Growth rate of natural phytop!ankton, estimated from synthesized chlorophyll-a, as a function of nitrate concentration; b) Linearization by plotting $S$ vs $S / \mu$, to give $K s$ and Vmax directly.
Table 3. Mean values percentage of utilization of nitrate and ammonium by Ubatuba region phytoplankton; nutrient quantity additioned was considered as $100 \%$ values

\begin{tabular}{lccc}
\hline & $\begin{array}{c}\text { Additioned } \\
\mu g-a t / 1\end{array}$ & $\begin{array}{r}\text { Detected } \\
\text { Hg-at/1 }\end{array}$ & \% utilized \\
\hline Ammonium & 6.87 & 0.60 & 91.12 \\
Nitrate & 7.46 & 2.42 & 71.71 \\
\hline
\end{tabular}


utilization. Table 3 shows that the percentage of ammonium utilization by the phytoplankton of Ubatuba was greater than that of nitrate. In the present work, the Ks values when estimated as cell number or synthesized chlorophyll- $a$ exhibited differences shown in Table 4 . These differences probably account for the low chlorophyl1- $a$ synthesis rate. Also, cell division going on after the nitrogen depletion may have occurred without chlorophyl1-a synthesis (McAllister et al, 1964). The Ks uptake rate values observed in this work
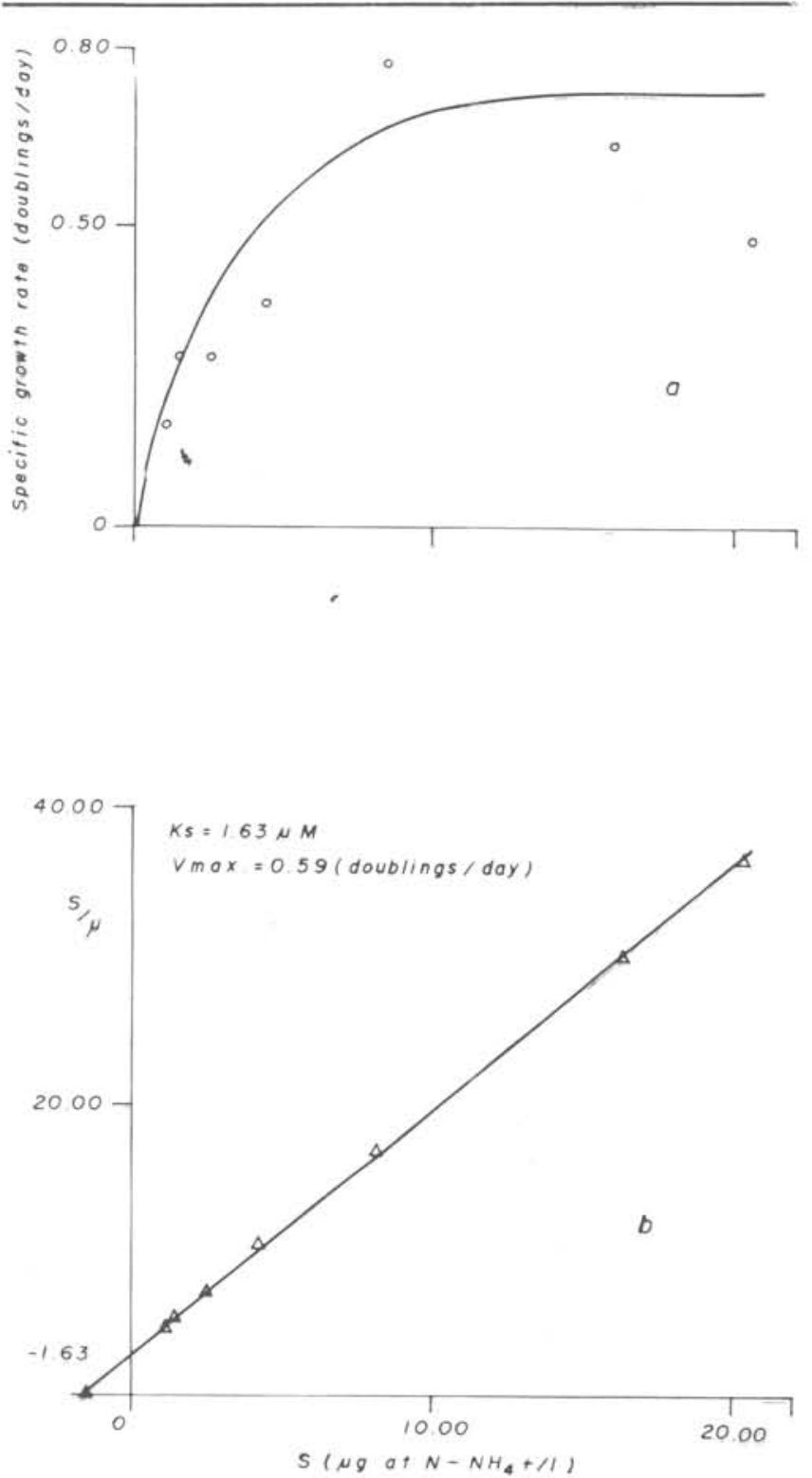

Fig. 7. a) Growth rate of natural phytoplankton, estimated from synthesized chlorophyll-a, as a function of ammonium concentration; b) Linearization by plotting $S$ vs $S / \mu$, to give $\mathrm{Ks}$ and Vmax directly.
Table 4. Values of $\mathrm{Ks}$ and Vmax estimated from cell number synthesized chlorophyll-a in nitrate and ammonium culture media; uptake rate $\mathrm{Ks}$ and Vmax in both media; the $95 \%$ confidence limits values could be attributed to sample size or experimental variat ion
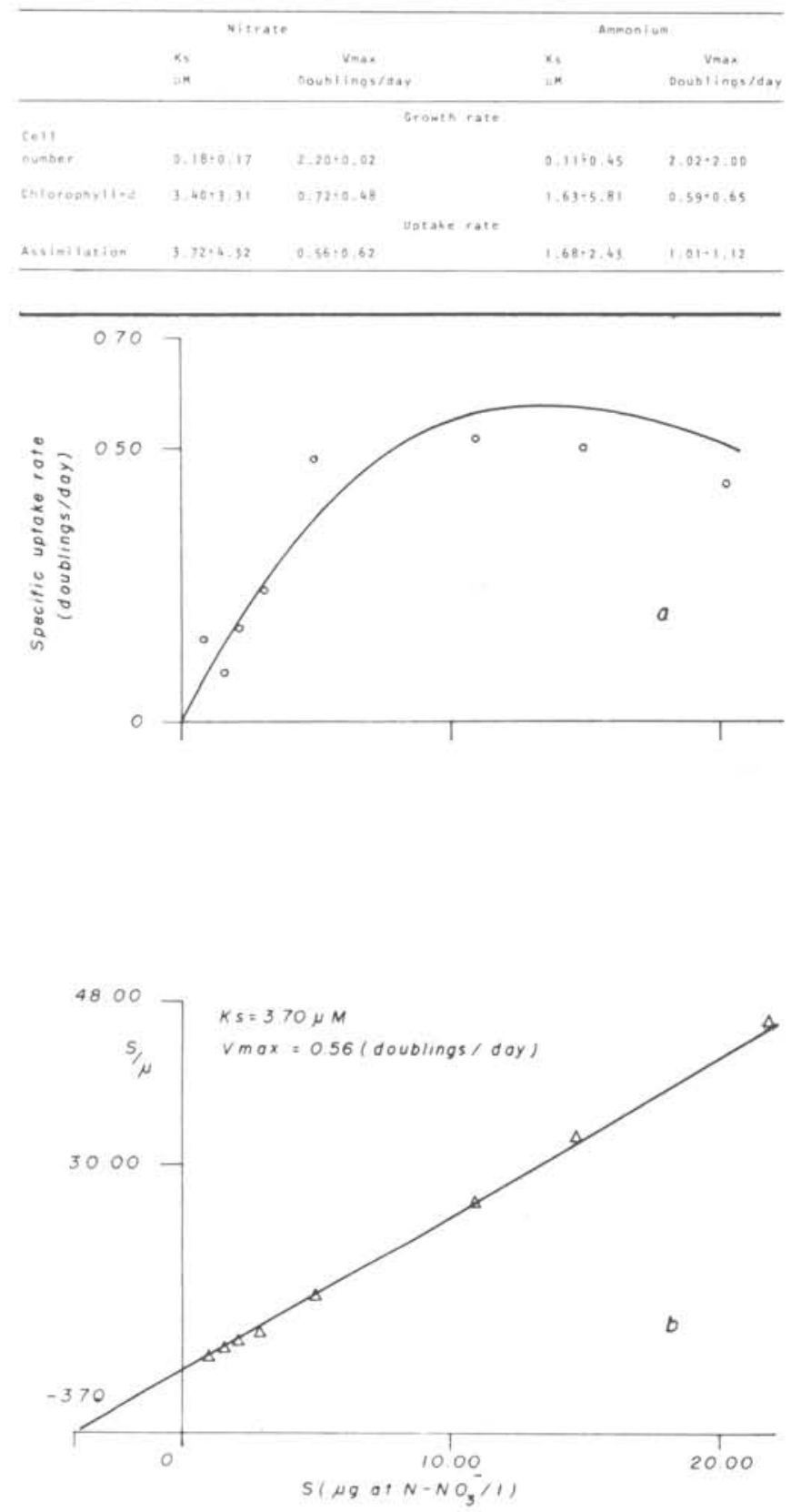

Fig. 8. a) Uptake rate of natural phytoplankton, estimated as nitrate consumption in the culture medium, as a function of nitrate concentration; b) Linearization by plotting $S$ vs $S / \mu$, showing directly Ks and $V \max$. 
were higher than those of Ks growth rate (Table 4), the difference being greater with nitrate data. Eppley \& Thomas (1969) suggested that Ks uptake rate constants are generally higher than those of Ks growth rate. Some new experiments must be carried on in the same region in order to confirm the results obtained hitherto. The affinity of the natural phytoplankton for ammonium must be confirmed (McCarthy et al., 1977). The Michaelis-Menten constants are
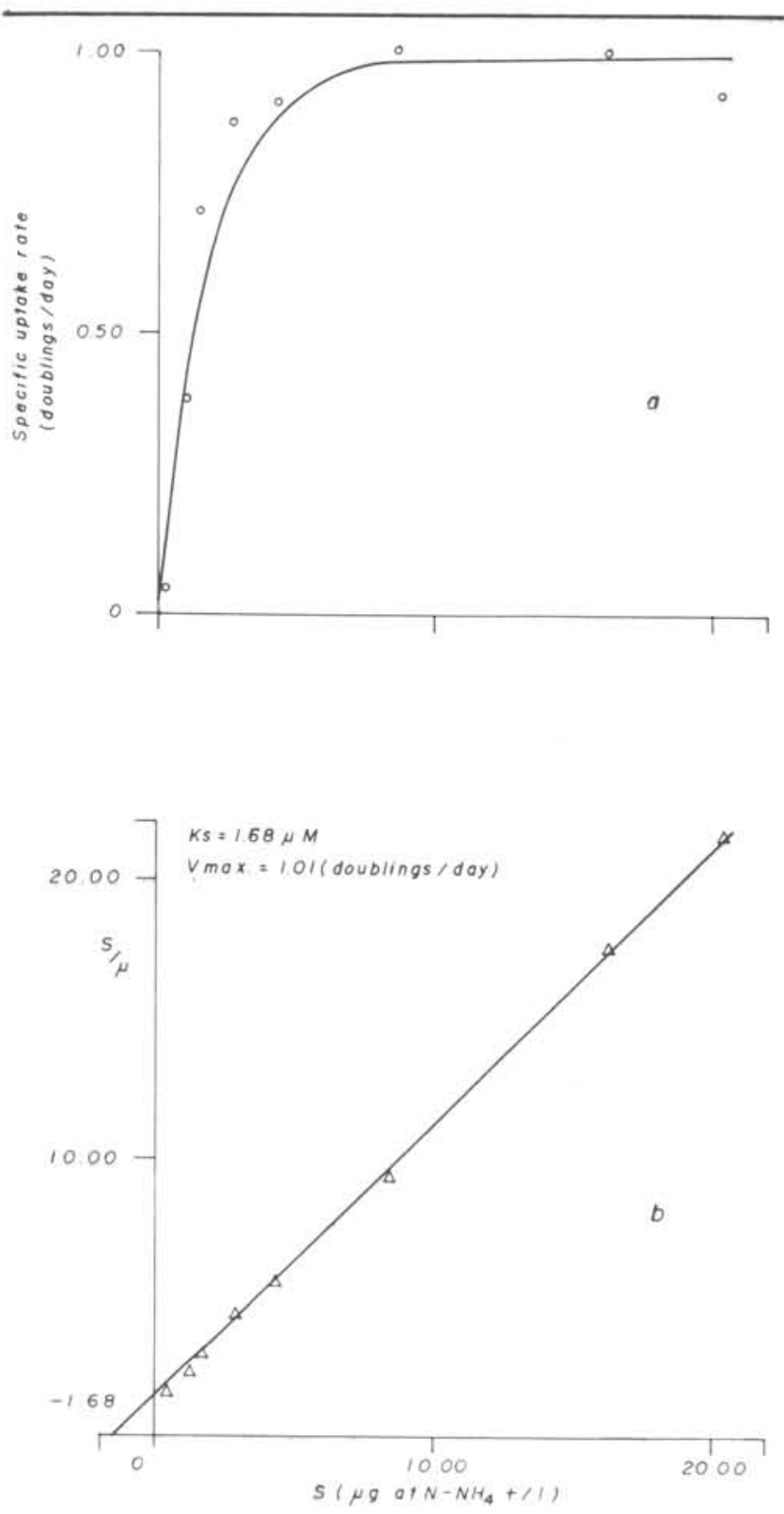

Fig. 9. a) Uptake rate of natural phytoplankton, estimated as ammonium consumption in the culture medium, as a function of ammonium concentration; b) Linearization by plotting $S$ vs $S / \mu$, showing directly Ks and $V \max$. important ecological parameters (Thomas \& Dodson, 1974) and would been determined for nutrients other than nitrate and ammonium and for other Brazilian regions.

\section{Resumo}

Foram determinadas a Ks e a Vmax do fitoplâncton natural, em função da concentração de amônia e nitrato. A velocidade de crescimento foi determinada como clorofila-a sintetizada e número de células no meio de cultura. A velocidade de assimilação foi determinada como o consumo de amônia e nitrato depois do esgotamento desses nutrientes do meio de cultura.

\section{References}

DROOP, M. R. 1974. The nutrient status of algal cells in continuous culture. J. mar. biol. Ass. U.K., 54:825-855.

DUGDALE, R. C. 1967. Nutrient 1imitation in the sea: dynamics, identification and significance. Limno1. Oceanogr., 12:685-695.

Uptake of new and regenerated forms of nitrogen in primary productivity. Limnol. Oceanogr., 12:196206.

EPPLEY, R. W. \& THOMAS, W. H. 1969. Comparison of half-saturation constants for growth and nitrate uptake of marine phytoplankton. J. Phycol., 5(4):375-379.

GOLDMAN, J. C.; MCCARTHY, J. J. \& PEAVEY, D. G. 1979. Growth rate influence on the chemical composition of phytoplankton in oceanic waters. Nature, Lond., 279(5710): 210-215.

HASLE, R. G. 1978. Identification problems: general recommendations. In: Sournia, A. ed. - Phytoplankton manual. Monogr. Oceanogr. Methodol., (6) : 125-128.

MCALLISTER, C. D.; SHAH, N. \& STRICKLAND, J. D. H. 1964. Marine phytoplankton photosynthesis as a function of ligth intensity: a comparison of methods. J. Fish. Res. Bd Can., 21(1):159-181. 
MacCARTHY, J. J.; TAYLOR, W. R. \& TAFT, L. 1977. Nitrogenous nutrition of the plankton in the Chesapeake Bay. I. Nutrient availability and phytoplankton preferences. Limnol., Oceanogr., $22(6): 996-1011$.

MULLIN, J. B. \& RILEY, J. P. 1955. The espectrophometric determination of nitrate in natural waters, with particular reference to sea-water. Analytica chim. Acta, 12:646-480.

PARSONS, T. R.; HARRISON, P. J. \& WATERS, R. 1978. An experimental simulation of changes diatom and flagellates blooms. J. exp. mar. Biol. Ecol., $32: 285-294$.

SASSI, R. 1978. Variação sazonal do fitoplâncton e fatores ecológicos básicos da região do Saco da Ribeira (Lat. $23^{\circ} 30^{\prime} \mathrm{s}$, Long. $45^{\circ} 07^{\prime} \mathrm{W}$ ). Ubatuba, Brasil. Dissertação de mestrado. Universidade de São Paulo, Instituto Oceanográfico, $147 \mathrm{p}$.

SCHMIDT, G. 1982. Algumas observações sobre a cinética do fitoplâncton marinho. 1. Influência da concentração de nitrato e amônia na velocidade de crescimento e de assimilação desses nutrientes na diatomäcea Phaeodactylum tricornutum (Boh1in). Bolm Inst. oceanogr., S Paulo, 31 (2): 13-27.

SOLORZANO, L. 1969, Determination of ammonia in natural waters by the phenolhypochlorite method. Limnol., Oceanogr., 14:799-801.
STRICKLAND, J. D. H. \& PARSONS, T. R. 1968. A practical handbook of seawater analysis. Bull. Fish. Res. Bd Can., (167):1-311.

TEIXEIRA, C. \& KUTNER, M. B. B. 1962. Plankton studies in a mangrove environment. I. First assessment of standing stock and principal ecological factors. Bolm Inst. oceanogr., S Paulo, 12:101-124.

\section{\& TUNDISI, J. 1967.} Primary production and phytoplankton in equatorial waters. Bull. mar. Sci., 17(4):884-891.

THOMAS, H. W. 1970. On nitrogen deficiency in tropical Pacific oceanic phytoplankton: photosynthesis parameters in poor and rich water. Limnol. Oceanogr., 15(3):380-385.

$$
\text { \& DODSON, A. N. } 1972 .
$$

Eutrophicalion in coastal waters: nitrogen as a controlling factor. Final Rep. U.S. Environm. Prot. Ag., Inst. mar. Resour., Univ. Cal. $67 \mathrm{p}$.

Effect of interactions between temperature and nitrate supply on the cell-division rates of two marine phytoflagellates. Mar. Biol., 24:213-217.

(Received 14-Dec-1981; accepted 06-0ct-1983) 